\title{
ALLOCENTRIKUS ÉS EGOCENTRIKUS TÉRI REFERENCIAKERETEK KAPCSOLATA A SZORONGÁSOS ÉLMÉNYEKRŐL ADOTT ÖNBESZÁMOLÓKKAL"
}

\author{
KÁLLAI JÁNOS, RÉVÉSZ GYÖRGY, HARTMAN MÓNIKA
}

Janus Pannonius Tudományegyetem, Pszichológia Intézet

E-mail: jkallai@btk.jpte.hu; revesz@btk.jpte.hu

\section{KARÁDI KÁZMÉR}

Pécsi Orvostudományi Egyetem, Magatartástudományi Intézet

E-mail: kazmer@cortex.pote.hu

\section{KÓCZÁN GYÖRGY}

Pécsi Orvostudományi Egyetem, Pszichiátriai Klinika

E-mail: koczang@apacs.pote.hu

Véleményünk szerint a különböző szorongásos tünetek jelentös része a környezet neuronális és kognitív reprezentációja során megjelenö zavarokra vezethetö vissza. E zavarok térról való élmény-és tudásreprezentációjában mutatkozó hibás beállitódásokban is tetten érhetök. A bemutatandó tanulmány a Tárgy mentális rotációs teszt (TMRT), valamint a Kéz mentális rotációs teszt (KMRT) segítségével a szorongás azon összetevöit tárja fel, melyek összefüggést mutatnak a téri szignálok kezelésének zavaraival. A két teszt hasonló mentális rotációs, döntési és perceptuális folyamatokat igényel. A különbség közöttük a rotáció menetében megalkotott referenciakeretek használatában van. Az TMRT esetében allocentrikus, KMRT esetében egocentrikus referenciakeret müködik aktivabban. A vizsgálatban 38 különbözö szorongásértékkel rendelkezö személy vett részt. Eredményeink szerint az allocentrikus és egocentrikus referenciahasználathoz különbözö típusú szimptómák kapcsolódnak. Az allocentrikus referencia domináns használatához a „Mit csinálok a környezetemben?”, míg az egocentrikus referenciákkal

A tanulmány az OTKA T-026558, valamint a James S. McDonnel Foundation Cognitive Neuroscience Program No. 98-69 támogatásával készült. 
dolgozó személyeknél az „Én milyen vagyok, hogyan értékelem magam?” típusú kérdéscsoportokban azonosithatók a szorongásos szimptómák. A mentális reprezentáció biológiai bázisát is bemutató interpretációink jelzik, hogy különbözö típusú szorongáshoz különböző típusú téri referenciakeret tartozik és a hátterében álló különbözö téri reprezentáció áll.

Kulcsszavak: $\quad$ allocentrikus, egocentrikus, téri orientáció, szorongás, mentális rotáció

A kognitív alapzavarok egyik megnyilvánulási formája a téri perceptuális és manipulációs képességek zavara. A téri tapasztalat multimodális, ebből adódóan az információ integrációja számos ponton zavart szenvedhet. Jelen tanulmányunkban a mentális tartalommal végzett téri mủveletek és a szorongás különböző típusainak kapcsolatát vizsgáljuk.

A percepció menetében létrejövő dinamikus képzet szekvenciális, motoros folyamatokon és döntéseken alapuló mentális képekkel végzett cselekvésekre épül (SHEPARD, METZler, 1971; SHEPARD, 1988). A mentális forgatás lényegében akaratlagos kontrollált lépésekben zajlik, a referenciakeretek pontos megválasztását és következetes fenntartását igényli (Williams, RipPON, STONE, ANNETT, 1995). A dinamikus képzet kialakításában részt vevő folyamatok: kódolás, keresés, forgatás, összehasonlítás, döntés és motoros válasz. A mentális rotáció folyamatát vizsgáló EEG térképezés, fMRI vizsgálatok tanúsága szerint biológiai tekintetben nincs lényeges agyfélteke-funkció különbség a mentális forgatás vonatkozásában (Corballis, Macadie, Beale, 1985; Deutsch, Bourbon, Papanicolaou, EisenBerg, 1988; Fischer, Pellegrino, 1988). Aktivitás tekintetében - a mentális forgatás multimodális funkciójából adódóan - a képzeti képpel végzett műveletek reprezentációjában, az elsődleges projekciós területek, a másodlagos asszociációs területek és a parietális cortexben lévő szenzomotoros területek vesznek részt a legintenzívebben a dinamikus képzetek megformálásában (ROLAND, LASSEN, Larsen, SkinhoJ, 1980; Finke, 1980; Breitling, Guenther, Rondot, 1986; Peronnet, Farah, 1989; Cohen, Kosslyn, Breiter, Di Girolamo, Thompson, ANDERSON, BOOKHEIMER, Rosen, BelliveaU, 1996; ANDERSEN, SNYDER, BRADLEY, XING, 1997). A mentális rotáció leggyakrabban alkalmazott vizsgáló eljárása a Tárgy mentális rotációs teszt (TMRT) (SHEPARD, METzLER, 1971; VANDENBERG, KuSE, 1978), melyben két dimenzióban ábrázolt kocka kombinációk különböző téri pozícióba való elfordítása a feladat lényege. fMRI vizsgálatok során megállapítást nyert (COHEN, KOSSLYN, Breiter, Di GIROLAMO, Thompson, ANderson, BoOKheimer, Rosen, Belliveau, 1996; ANdersen, SNYDER, BRAdLEY, XING, 1997), hogy a magas szintű mentális forgatási teljesítményt nyújtó személyeknél az agyi vérátáramlás lényegesen megnövekedett az inferio parietális és az occipitális cortex területén. A hatékony mentális forgatási képességgel rendelkező személyek magas szintű artikulált kognitív szerkezettel jellemezhetők, a feladat teljesítése közben agyi aktivitásuk kevésbé diffúz, inkább fokális jellegű. Ezt a véleményt CHARLOT és munkatársai (1992), valamint WiLLIAMS és munkatársai (1995) tanulmányai is alátámasztották. A magas szintü téri mentális forgatási képességek a közvetlen percepció hatásához hasonlóan 
intenzív fokális aktivációval járnak együtt a parietális cortex területén. Ugyanakkor a mentális rotáció során megvalósuló szándékos döntési folyamatok frontális aktivációt is létrehoznak (WILliams, RiPPON, STONE, ANNETT, 1995), továbbá a maguk konkrét jellegével emocionális és rövid távú téri emlékezési folyamatokat is mozgósítanak (PAILLARD, 1991; JACOBS, NADEL, 1985; NADEL, JACOBS, 1996).

A mentális forgatás közben alkalmazott referenciainformációk felhasználása azonban individuális különbségeket mutat (Linn, Petersen, 1985; Casey, COlON, GORIS, 1992; UeCker, ObruZuT, 1993). Dominánsan belső (internal) vagy külső (external) kódolási stratégiák aktiválódnak (ISAAC, MARKs, RUSSEL, 1986). A belső mind motoros, mind kinesztetikus szignálokra épít, míg a külső szignálokra beállított kódolás dominánsan a vizuális információkra koncentrál. A szorongás klinikai aspektusait vizsgáló kutató szempontjából ki kell emelnünk, hogy e kódolási különbség individuális hatásaival a percepció kutatás általában nem számol, de ugyanakkor ezen individuális különbségek a klinikai kutatások vonatkozásában sem állnak előtérben, annak ellenére, hogy a kognitív kutatások a kognitív alapzavarok regisztrálására összpontosítanak. Az idegtudomány fogalomrendszerére lefordítva, az említett belső referenciákra támaszkodó téri információkezelés a proximális jelzésekre épített egocentrikus, míg a külső, a disztális jelzésekre épített allocentrikus referenciákra támaszkodik (O'KEEFE, NADEL, 1978). A proximális és disztális jelzések hatékony felhasználása ökológiailag fontos szerepet lát el. Különböző téri szignálok tanulása a hippocampusal és a parietális cortexel összefüggő agyi területek kontrollja alatt áll (O'KEEFE, NADEL, 1978; MORRIS, 1981).

Az egocentrikus és az allocentrikus téri referenciák a közelítő és a visszavonuló magatartás szabályozásának kereteit adják. Az egocentrikus referencia alapján a személy azt dönti el, hogy egy esetleges veszély szignál „merre”, hozzá képes milyen irányban és távolságban, az allocentrikus alapján pedig, hogy „hol”, a disztális tárgyak, személyek egymáshoz viszonyított helyzete alapján megszerkesztett térkép melyik pontján helyezkedik el. Az egocentrikus tér mentális reprezentációjának szervezését a poszterior parietalis cortex látja el (ANDERSEN, 1988), e terület sérülése határozottan károsítja az egocentrikus tér percepcióját (ANDERSEN, 1988; STEIN, 1992).

Néhány évvel ezelőtt BONDA és munkatársai (1995) kifejlesztettek egy olyan mentális rotációs tesztet, amely nem allocentrikus helyzetű tárgyak, formák vagy betűk, hanem egocentrikus referenciát involváló különböző helyzetben lévő jobb, illetve bal kezek fényképéből állt.

A kéz motoros és szenzoros reprezentációját egy jól elkülönült parietális cortex terület kontrollálja. Agysérülések következtében kialakult kognitív deficiteket feltérképező és egy sejtre lokalizált neuronális aktivitás vizsgálatok alapján a superior parietális lebeny, valamint a szomszédos intraparietális sulcust körülvevő anterior rész rostralis területe kódolja a testrészek pozícióját és elhelyezkedését. Ez a terület központi szerepet vállal a testkép és a hozzá kapcsolódó tudatos testi élmények megformálásában. Bonda és munkatársai feltételezték, hogy a Kéz mentális rotációs teszt (KMRT) megoldása során, a jobb, illetve a bal kéz pozíciójának meghatározásakor, az említett agyi területek kiemelt aktivitása nélkülözhe- 
tetlen a hatékony teljesítmény kivitelezésében. KMRT közben végzett pozitron emissziós tomográfiás (PET) vizsgálat során kimutatták, hogy a jobb és a bal agyfélteke superior parietális lebenye egyaránt aktiválódik a teszt megoldása során. Ezek az intraparietális sulcus első területeit magában foglaló képletek az elsődleges szomatoszenzoros kéreg információi alapján építik fel a testtartás, a testkép mentális reprezentációját. További leírásuk szerint az insula anterodorsalis része kapcsolatban áll a limbikus rendszerrel, s így a testkép az emocionális szignálokkal együtt kerül megformálásra. BONDA és munkatársai (1995) vizsgálati adatai, a parietális cortex múködéséről rendelkezésre álló anatómiai és fiziológiai ismereteink fényében bizonyítják, hogy a bal intraparietális sulcus, a vesztibuláris, szomatoszenzoros, visuospatialis és oculomotoros inputok együtt vesznek részt a mentális forgatás folyamatában.

\section{KÉRDÉSFELVETÉS}

Az eddigieket figyelembe véve megállapíthatjuk, hogy a parietális lebeny központi szerepet játszik a mentális forgatás folyamatában. Az inferior parietális lebeny és a bal intraparietális sulcus mind az allo-, mind az egocentrikus téri információfeldolgozást szabályozza. fMRI adatok szerint mindkét esetben a bal intraparietális sulcus és a superior parietális lebeny aktiválódik. Ugyanakkor lényeges különbség, hogy az ego- vagy allocentrikus referenciakeretek használatakor a limbikus információkhoz jobban kötődő insula különböző módon aktiválódik.

Mindezek alapján úgy látjuk, hogy az egocentrikus és az allocentrikus referenciakeretet szolgáltató neurális háttér, a különböző referenciakereteket igénylő mentális rotációs feladatok esetén, eltérő aktivitás szintet mutat. Az egocentrikus referenciakeret emocionális involváltságára számos bizonyíték van. Fejlődéslélektani bizonyítékok is utalnak arra, hogy az ego- és allocentrikus referenciakeretek használata egymással kényes, a fejlődés menetében is megzavarható viszonyban van (PAILLARD, 1991). A neuronális magyarázatok mellett úgy látjuk, hogy a kognitív alapzavarok kutatásában e referenciarendszerek együttműködésének vizsgálata rávilágíthat a szorongásos zavarok kialakulásának egyik vonulatára.

Korábbi munkáink során (KÁllai, KóCZÁN, SZABÓ, MOLNáR, VARGA, 1995; KÁLlAi, SZABADOS, VARGA, OZSVÁTH, MOLNÁR, KÓCZÁN, 1996) felvetettük, hogy a pánik és az agorafóbiás betegeknél tapasztalható szorongás, más szorongástípushoz viszonyítva a téri memória, a téri szignálok kezelésének zavarával jár együtt. Az eddigiek során még nem látjuk pontosan, hogy a tér kognitív torzulásai aktuális szorongás vagy egy általános figyelmi beállítódás hatásának tekinthetők-e. Jelen vizsgálatunk elsődleges célja a mentális rotáció során végzett téri műveletek egyes szorongásmutatókkal való összevetése, illetve a háttérben álló neuropszichológiai mechanizmus elemzése.

A patológiás és normál szorongás egyaránt lényegesen befolyásolja az egyes kognitív feladatokban nyújtott teljesítményt. Feltételezzük, hogy a szorongásoktól szenvedő személyek emocionálisan hangsúlyozott állapotaihoz kapcsolódó emocionális feszültség, a korábbiakban részletezett neuropszichologiailag definiált állo- 
másokon befolyásolja, illetve modulálja a mentális rotáció folyamatát. A vizsgálat menetében két fő változót elemeztünk; az egyik a szorongás típusa, a másik a különböző téri referenciákra építő mentális forgatási teljesítmény.

Explorativ munkánk első fő kérdése annak a tisztázása, hogy vajon a kérdőíveken keresztül mért, érzékszervi vagy intellektuális fogyatékossággal nem rendelkező középiskolás személyeknél regisztrálható szorongás milyen módon kapcsolódik a különböző téri referenciákra épülő mentális forgatási teljesítményekkel.

\section{Személyek}

A vizsgálatban, órák után, önkéntes részvétel alapján 51 negyedéves középiskolás közül az abszolút jobbkezesség kritériumait figyelembe véve 38 fő került kiválasztásra. Életkortartomány: min.: 17, max.: 19 év, nemek tekintetében 19 férfi (átlagéletkor: 18 év $s=0,70$ ) és 19 nő (átlagéletkor: 17,6, $s=0,57$ ), a minta homogénnek tekinthető.

\section{Eljárás}

KÉZHASZNÁLAT: Chapman Kezességi kérdőíve (Handedness Questionnaire) alapján felmértük a személyek kézhasználati preferenciáját (a kérdőívet ANNETT [1970] kérdőívének empirikus elemzése alapján CHAPMAN, L. J. és Chapman, J. P. [1987] állította össze). A kérdőív 13 cselekvésformát ír le. A személynek állást kell foglalnia, melyik kezével végzi ezeket a cselekvéseket. A vizsgálat első részében elvégzett kezességi teszt kitöltése után a vizsgálat további szakaszában csak a maximális jobb kéz használati pontszámmal rendelkező személyek vettek részt.

FÉLELEM: A WOLPE és LANG (1977) és ARRINDELl (1993) által kidolgozott Félelmet felmérő lista (Fear Survey Schedule FSS) több félelmi faktort foglal magába: I. Szociális félelem (SzocF), II. Agorafóbia (AgoraF), III. Halál és betegség félelem (BetF), IV. Szexuális és agresszív jelenetek félelem (SexF) és V. Félelem az állatoktól (ÁllatF). A személyeknek különböző élethelyzetekben mutatott félelmeikről kellett beszámolót adniuk egy 0-4-ig terjedő skála segítségével. A kérdőív alapján a személyek félelmeinek fajtája és a mindennapokra vonatkoztatott elkerülő magatartás intenzitása mint speciális félelmeket kiváltó helyzetek elkerülésére vonatkozó együttes pontszám került meghatározásra.

SZORONGÁS: Spielberger vonásmérő szorongástesztjét használtuk (Trait Personality Inventory - SPIELberger, Jacobs, Crane, Russel, Westberry, BARKER, JOHSON, KNIGHT, MARKS, 1980; OlÁH, 1987) a személyek általános szorongásosságának meghatározására. A kérdőív az alábbi faktorokat tartalmazza: I. Szorongásosság (Szor), II. Kíváncsiság (Kiv), III. Düh (Düh). A személyeknek önmagukat kellett értékelniük, érzéseikről, diszpozícióikról kellett véleményt mondaniuk egy 1 -től 4 -ig terjedő skála segítségével. 
TÉRI KÉPESSÉGEK: Tárgy mentális rotációs teszt (TMRT): Allocentrikus térészlelés vizsgálatára használható teszt (SHEPARD, METZLER, 1971), melynek VANDENBERG és KUSE (1978) által módosított papír-ceruza változatát használtuk. A TMRT 20 tételből áll. Az egyes ábrák háromdimenziós elrendezésű tárgyak, illetve kockák rajzai. Minden tétel tartalmaz egy célábrát, és annak pontosan megfelelő két térben elforgatott változatát (például a célábra tükörképe), valamint két zavaró ábrát. A személynek el kell döntenie, hogy a négy ábra közül melyik kettő azonos a bal oldalon található célábrával. Az értékelésnél két pont jár a hibátlan megoldásért, egy pont, ha csak az egyiket jelöli meg. A teszt kitöltésére rendelkezésre álló idő hat perc, melyből három perc jut az első tíz tételre és három a második tízre.

Kéz mentális rotációs teszt (KMRT) (BONDA, Petrides, Frey, Evans, 1995): A klaszszikus allocentrikus mentális rotációs tesztekben (TMRT) a személy 2 különböző fokban rotált tárgyat viszonyít egymáshoz és így ítéli meg a közöttük lévő hasonlóságot. Az egocentrikus mentális rotációs feladat (KMRT) ettől annyiban tér el, hogy a döntés, illetve a forgatás folyamata nagymértékben támaszkodik a saját test aktuális pozíciójára utaló információkra. A döntés a bemutatott különböző szögben elforgatott kéz jobb vagy bal mivoltára vonatkozik (ez a döntési folyamat intenzíven involválja a parietális cortex működését). A teszt méri, hogy a vizsgált személy milyen gyorsan és mennyi hibával képes eldönteni, hogy a látott kéz képe jobb vagy bal kézről készült. A teljes vizsgálati anyag négy tesztlapot tartalmaz. Mindegyik lapon $20 \mathrm{db} 5 \times 4$-es mátrixban rendezett kéz képei láthatók. Az első lap 0, a második 50, a harmadik 90, a negyedik $180^{\circ}$-ban, az óra járásával megegyező irányban elforgatott kezek képeit tartalmazza $\left(180^{\circ}\right.$-os demonstrációs lapot lásd 1. ábra). A személynek mindegyik lapnál balról jobbra haladva sorról sorra el kell döntenie, hogy jobb vagy bal kezet lát. A vizsgálat vezetője mindegyik feladatlapnál méri a teljesítés idejét, valamint regisztrálja a hibás válaszok számát. A kiértékelés során mindegyik rotációs foknál egy megoldási időt (másodpercben) és egy hibaszámot kapunk. Az adatok elemzése során a különböző rotációs adatokat összevontuk. Az így kapott rotációs latencia a személyek mentális forgatásának hatékonyságát mutatja. 


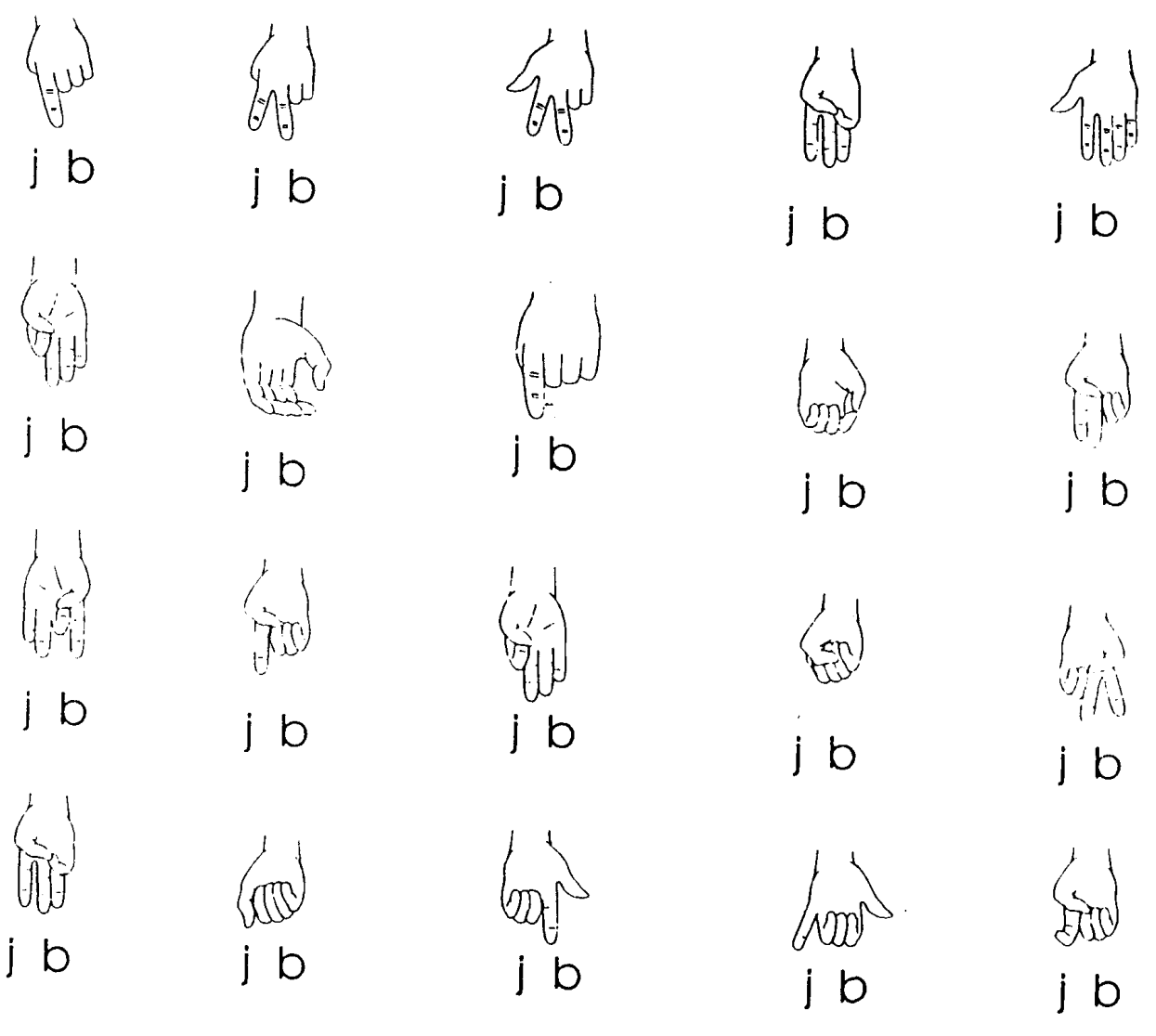

1. ábra. BONDA és munkatársai (1995) által szerkesztett Kéz mentális rotációs teszt $180^{\circ}$-os tesztlapja

\section{Eredmények}

Első lépésben a több változó egyszempontos elemzését lehetővé tevő ANOVA teszttel vizsgáljuk meg a csoportok között a nemi (férfi v.s. nő) különbségek hatását az alábbi változók esetén: TMRT, KMRT, Szor, Kiv, Düh, SzocF, AgoraF, BetF, SexF, és ÁllatF. Szignifikáns különbség csak a TMRT esetén mutatkozott, $\mathrm{F}(1,36)=16,21, \mathrm{P}<0,001$ (1. táblázat). A férfiak hatékonyabb mentális rotációs képességekkel rendelkeznek, mint a nők. Ez az eredmény illeszkedik VANDENBERG és KUSE (1978) vizsgálati eredményeihez, mely szerint fajtól, kultúrától, szociális osztálytól függetlenül a férfiak a TMRT-ben hatékonyabb teljesítményt nyújtanak. Ugyanakkor látjuk (1. táblázat), hogy az egocentrikus rotációs feladatban és a szorongás és félelem faktorokban nincs lényeges nemi különbség a vizsgált csoportban. 
1 táblázat. Mentális forgatás, félelem- és szorongáskülönbségek a férfiak és a nők között

\begin{tabular}{|c|c|c|c|c|c|}
\hline Változók & Nem & Átlag & $\begin{array}{l}\text { Standard } \\
\text { deviáció }\end{array}$ & F-érték & Szignifikancia \\
\hline \multirow[t]{2}{*}{ TMRT } & Nő & 12,10 & 5,36 & 16,21 & $\mathrm{p}<0,001$ \\
\hline & Férfi & 21,84 & 6,53 & & \\
\hline \multirow[t]{2}{*}{ KMRT } & Nő & 69,73 & 7,78 & 0,68 & n.s. \\
\hline & Férfi & 72,00 & 9,07 & & \\
\hline \multirow[t]{2}{*}{ Szor } & Nő & 21,84 & 5,98 & 3,66 & n.s \\
\hline & Férfi & 18,68 & 3,98 & & \\
\hline \multirow[t]{2}{*}{ Kiv } & Nő & 28,26 & 6,37 & 2,23 & n.s \\
\hline & Férfi & 31,26 & 3,67 & & \\
\hline \multirow[t]{2}{*}{ Düh } & Nő & 25,15 & 5,44 & 0,32 & n.s \\
\hline & Férfi & 24,21 & 4,69 & & \\
\hline \multirow[t]{2}{*}{ SocF } & Nő & 21,73 & 6,87 & 2,63 & n.s. \\
\hline & Férfi & 17,00 & 10,10 & & \\
\hline \multirow[t]{2}{*}{ AgoraF } & Nő & 7,78 & 4,14 & 0,44 & n.s. \\
\hline & Férfi & 6,73 & 5,48 & & \\
\hline \multirow[t]{2}{*}{ BetF } & Nő & 15,52 & 8,16 & 0,71 & n.s. \\
\hline & Férfi & 12,94 & 10,53 & & \\
\hline \multirow[t]{2}{*}{ SexF } & Nő & 7,57 & 1,43 & 1,44 & n.s. \\
\hline & Férfi & 5,94 & 1,82 & & \\
\hline \multirow[t]{2}{*}{ ÁllatF } & Nő & 7,15 & 1,18 & 3,92 & n.s \\
\hline & Férfi & 4,42 & 1,33 & & \\
\hline
\end{tabular}

Második lépésben a TMRT és KMRT, valamint a szorongás, félelem kérdőívek faktorainak kapcsolatát vizsgáltuk faktoranalízis módszerével (SPSS-PC 1994), (2. táblázat).

2. táblázat. Mentális forgatás, szorongás és félelem különböző értékeinek faktoranalízise

\begin{tabular}{|l|c|c|c|}
\hline Változók & 1. faktor & 2. faktor & 3. faktor \\
\hline ÁllatF & $\mathbf{, 8 8 8 2}$ &, 1608 &, 0621 \\
\hline AgoraF & $\mathbf{, 8 2 5 7}$ &, 0467 &,- 1973 \\
\hline BetF & $\mathbf{, 7 9 1 5}$ &, 0851 &,- 1363 \\
\hline SexF & $\mathbf{, 7 8 5 1}$ &, 2298 &, 0181 \\
\hline SzocF &, 2112 & $\mathbf{, 8 8 8 1}$ &, 1309 \\
\hline Szor &, 2090 & $\mathbf{, 7 1 4 6}$ &,- 3201 \\
\hline TMRT &,- 0390 & $\mathbf{- , 6 4 3 2}$ &, 3311 \\
\hline KMRT &, 0061 &,- 1483 & $\mathbf{7 5 7 6}$ \\
\hline Düh &, 0561 &, 0603 & $\mathbf{- , 7 2 3 9}$ \\
\hline Kiv &,- 4322 &,- 2009 & $\mathbf{, 5 0 3 9}$ \\
\hline
\end{tabular}

Rotált faktor mátrix: $\quad$ Kaiser-Meyer-Olkin Adequacy $=0,70 \quad$ Cum Pct $=65,00$ 
A statisztikai eljárással szelektált három faktor világosan mutatja a félelmi válaszokat involváló alskálák viszonylagos egységességét. Az első faktorban lényegében az archaikusabb állatfélelem és a szintén archaikusabb forrásból táplálkozó agorafóbia a meghatározó. Ezért az 1. faktort Archaikus vagy agorafóbiás félelem faktornak nevezhetjük. A második faktorban a TMRT és a SzocF, valamint a Szor együttjárását láthatjuk, mely szerint a rossz TMRT teljesítmény rendszerint magas SzocF, valamint Szor értékekkel jár együtt. Korábbi vizsgálatok tanúsága szerint (ARRINDELL, 1993) a szociális fóbia és a szorongásosság általában magas korrelációs együtthatóval kapcsolódik egymáshoz, amely alapján a 2. faktort a Külsó szociális térre összpontositó szorongásosság faktoraként definiálhatjuk, amelyben a magas szorongás deficites allocentrikus téri információfeldolgozással jár együtt. A 3 . faktor tekintetében azt a korlátozott érvényủ megállapítást tehetjük, hogy a KMRT mint vezető faktor az Egocentrikus térre vonatkozó kíváncsiságot involváló törekvéseket támogatja, de ugyanakkor visszaszorítja a kifelé irányuló agresszív indulatokat. Meg kell jegyeznünk, hogy a faktoranalízis eredményeiben interpretált, allocentrikus disztális referenciapontokra támaszkodó és egocentrikus proximális támpontokra építő magyarázatnak a szorongás különböző mutatóival való összevetése pillanatnyilag hipotézisnek tekinthető, az adatok csupán utalnak erre a lehetőségre, de nem bizonyítják ennek tényleges létét. Ebből adódóan a faktoranalízis eredményét csupán hipotézisgeneráló, de nem bizonyító értékủ leletnek tekintjük. A további elemzések feladata e hipotézis vizsgálata.

A további kérdések megválaszolásához a félelem (FSS) (52 tétel) és szorongás (STAI) (40 tétel) kérdőívek tételeinek vizsgálatától remélünk további támpontokat. A következő lépésben megvizsgáltuk a különböző kérdőív itemek és az TMRT, valamint a KMRT teljesítmények kapcsolatát. A többszörös regresszió vizsgálatának eredményét a 3. táblázat tartalmazza. (STAI tételek megtalálhatók OLÁH [1987] FSS kérdőív tételei: The fear of fear concept: Behavior Research and Therapy, 1993, 31, 507-518.)

Értelmezésünk szerint a különböző referenciakeretekre épülő mentális rotációs tevékenység a szorongás, félelem tételek közül különböző típusú kérdésekkel mutat kapcsolatot. A TMRT teljesítmény alacsony értékei együtt járnak az idegen helyek $(\mathrm{p}<0,01)$, nyilvános helyek $(\mathrm{p}<0,05)$, zsúfolt terembe való belépés $(\mathrm{p}<0,02)$, idegenekkel való találkozás $(\mathrm{p}<0,02)$, emberi vérrel való találkozás $(p<0,05)$, a mellőzés $(p<0,05)$ elkerülésével, valamint olyan helyzetekben való félelemmel, melyben az ember mások kritikájának a tárgya $(\mathrm{p}<0,05)$, valamint mikor mások figyelik őt, miközben a munkáját végzi $(p<0,02)$. Korreláció mutatkozik továbbá a magabiztosság hiánya $(p<0,02)$ és a szellemi aktivitás hiányának érzésével $(\mathrm{p}<0,01)$. Nem tartanánk célravezetőnek a rendelkezésre álló adatokból az adott itemek és a TMRT teljesítmény között ok-okozat viszonyt feltételezését. Ettől függetlenül a kapcsolat ténye egy jelenség lényeges mozzanatára utal. Mielött ennek kifejtésére rátérnénk, vizsgáljuk meg a KMRT és a szorongás-félelem tételek kapcsolatát. A KMRT-ben mutatott rossz teljesítmény az alábbi tételekkel mutat kapcsolatot. Idegesnek érzem magam $(\mathrm{p}<0,05)$, abnormálisnak érzem magam $(p<0,01)$, általában nem vagyok kíváncsi $(p<0,05)$, nincs bennem energia 
3. táblázat. Szorongás és félelem kérdőív tételeinek szingnifikáns korrelációi a TMRT, valamint a KMRT teljesítményekkel. Többszörös regresszióanalízis

\begin{tabular}{|c|c|c|}
\hline A szignifikáns függő változók & F-érték & Szignifikancia \\
\hline \multicolumn{3}{|c|}{ Tárgy mentális rotációs teszt: } \\
\hline Idegen helyek & 11,77 & $\mathrm{p}<0,001$ \\
\hline Nyilvános helyek & 5,08 & $\mathrm{p}>0,02$ \\
\hline Belépés egy zsúfolt helységbe & 6,39 & $\mathrm{p}<0,02$ \\
\hline Idegen emberrel való találkozás & 5,54 & $\mathrm{p}<0,02$ \\
\hline Figyel valaki munkavégzés közben & 5,48 & $\mathrm{p}<0,02$ \\
\hline Valaki kritizálja a tevékenységemet & 4,21 & $\mathrm{p}<0,05$ \\
\hline Emberi vérrel való találkozás & 4,62 & $\mathrm{p}<0,05$ \\
\hline Figyelmen kívül hagyják a tevékenységemet & 5,19 & $\mathrm{p}<0,05$ \\
\hline Nem vagyok magabiztos & 5,92 & $\mathrm{p}<0,02$ \\
\hline Mentálisan visszafogott vagyok & 7,43 & $\mathrm{p}<0,01$ \\
\hline \multicolumn{3}{|c|}{ Kéz mentális rotációs teszt: } \\
\hline Ideges és nyugtalan vagyok & 4,31 & $\mathrm{p}<0,05$ \\
\hline Úgy érzem, nem vagyok normális & 7,69 & $\mathrm{p}<0,01$ \\
\hline Nem vagyok kiváncsi & 4,28 & $\mathrm{p}<0,05$ \\
\hline Elvesztettem az energiámat & 5,11 & $\mathrm{p}<0,05$ \\
\hline Gyenge vagyok & 4,22 & $\mathrm{p}<0,05$ \\
\hline Elvesztettem az érdeklődésemet & 7,95 & $\mathrm{p}<0,01$ \\
\hline Gyakran unatkozom & 6,56 & $\mathrm{p}<0,02$ \\
\hline
\end{tabular}

$(p<0,05)$, gyengének érzem magam $(p<0,05)$, elvesztettem az érdeklődésemet $(\mathrm{p}<0,01)$, gyakran unatkozom $(\mathrm{p}<0,02)$, Az eredmények alapján megállapíthatjuk, hogy a TMRT és a KMRT különböző típusú kérdésekkel mutat korrelációt. Az értelmezés menetében elsősorban nem a tételek jelentésére, hanem a tartalom megfogalmazásának módjára érdemes összpontosítani. Meggyőződésünk szerint a többszörös regresszióvizsgálat eredménye arra utal, hogy a gyenge TMRT teljesítmény a szorongás azon kifejezési formáival mutat kapcsolatot, melyben a disztális térben végzett akciókat minősíti a személy, míg a KMRT teljesítmény a önértékeléshez, proximális referenciához kötődő szorongásos tartalmakkal mutat kapcsolatot. Úgy tủnik tehát, hogy a TMRT és a KMRT teljesítmények hátterében álló kognitív és neuropszichológiai mechanizmusok olyan kifejezési mód modulációjában vesznek részt, melyek hatnak a szorongás formai elemeinek artikulációjára. Figyelembe véve, hogy korábbi adataink a KMRT és az TMRT között nem mutatnak lényeges kapcsolatot, a fentiekben kifejtett allocentrikus vagy egocentrikus referenciakeretre építő modulációs sajátosságok az individuális szorongáskezelő stratégia részének tekinthetők. 


\section{Megivitatás}

Adataink szerint a TMRT-ben mutatott téri funkciók tekintetében a férfiak jobb teljesítményt nyújtanak, mint a nők. Ez a nemhez kötődő képességegyüttes az allocentrikus téri referenciaszignálok hatékonyabb kezelését foglalja magába. E tekintetben adataink illeszkednek VANDENBERG és KUSE (1978), SANDSTROM és munkatársai (1998) eredményeihez. A KMRT esetében hasonló nemi különbséget nem találtunk. A KMRT esetén a hiányzó nemi különbség okát további vizsgálatoknak kell tisztáznia. A vizsgálat közben tett nem operacionalizált megfigyeléseink szerint a KMRT közben az egocentrikus referenciákat mozgósító feladat megoldása során a nők lényegesen gyakrabban kisérték spontán verbalizációval a megoldás menetét, mint a férfiak. E jelenség arra utal, hogy a különböző téri referenciakeretek használata a hölgyek esetén olyan egocentrikus referenciákhoz kötődő verbális tevékenységgel egészül ki, mely nők esetében növeli az egocentrikus tájékozódás hatásfokát és elmossa a férfiak és a nők közötti különbségeket.

A faktoranalízis eredményeit figyelembe véve megállapítottuk, hogy az adatok három faktorba rendezhetők: 1. faktor: Az archaikus forrásból táplálkozó félelem, 2. faktor: Külső szociális térre összpontositó szorongásosság és a 3. faktor: az Egocentrikus térre vonatkozó kíuáncsiság. A fóbia és a szorongás különböző védekezési típust jelez. A fóbia definiált helyekre vonatkozó elkerülő aktivitással jár együtt, míg a szorongás általánosabb, nem a kontextus, hanem maga a személy perszonális lehetőségei és kontrollképessége kerül előtérbe, melyben a saját tevékenységére és személyére vonatkozó értékelésnek van vezető szerepe. Különböző típusú szorongás hátterében különböző típusú kognitív és neuropszichológiai struktúra áll (BECK, EMERY, Greenberg, 1985; Marks, 1987; Gorman, Leibowitz, Fyer, Stein, 1989; MARGRAF, EHLERS, 1989).

A mentális rotáció különböző formájának és a szorongásos tételek összefüggésének vizsgálata meglepő eredménnyel szolgált. A korrelációk alapján láthattuk, hogy az allocentrikus vagy az egocentrikus referenciakeretre épülő mentális forgatási teljesítmény összefüggést mutat a különböző formában kifejtett szorongástételekkel. Meglátásunk szerint a kapcsolatok elemzésében nem a tételek tartalmára, hanem azok kifejezési formájára kell fordítanunk a figyelmünket. Megállapíthatjuk, hogy a gyenge allocentrikus referenciákra építő mentális forgatási teljesítmény azokkal a tételekkel mutat kapcsolatot, melyekben a „Mit csinálok a környezetemben, különböző helyzetekben?” típusú szituatív félelmeket tartalmazó tételek jelennek meg. Ugyanakkor az alacsony egocentrikus mentális forgatási teljesítményt mutató személyek esetén a „Milyen vagyok, hogyan értékelem önmagam?” típusú szorongást involváló kérdésekkel mutatkozik kapcsolat.

Figyelembe véve a rendelkezésünkre álló adatokat és az irodalomban szereplő, a mentális rotációval kapcsolatos neuropszichológiai interpretációkat, jelen adatainkat az említett kontextusban az alábbiak szerint értelmezhetjük. A két különböző mentális rotációs feladat különböző típusú szorongásos tételekkel mutat kapcsolatot, ugyanakkor a fMRI vizsgálatok feltárták (STEIN, 1992, TAGARIS, Kin, Strupp, Andersen, Ugurbil, Georgopoulos, 1996; Andersen, Snyder, 
BRADLEY, XING, 1997), hogy a TMRT és a KMRT hátterében eltérő lokalizációjú és funkciójú neuronális organizáció áll. Megítélésünk szerint ezen eltérő organizációk szerepet játszanak a szorongásos tételekre adott válasz vagy maguk a szorongásos tünetek megjelenési módjának modulálásában. Feltételezzük, hogy a környezetre, a szituációkra irányuló figyelemmel együtt járó allocentrikus feldolgozási módnak speciális szorongásos szimptómák megjelenítésében is szerepe lehet.

Eredményeink szerint a szorongás különböző típusa különböző téri reprezentációs móddal, illetve téri referenciakeret használatával jár együtt. Látható, hogy a személyre jellemző domináns téri reprezentációs mód mint egy rejtett modulációs folyamat befolyásolja a szorongás megjelenési módját. A szorongásos tünetek megjelenésének módja a perceptuális és kognitív apparátus beállítódásaitól függ. $\mathrm{Az}$ a személy, aki rossz teljesítményt nyújt az egocentrikus KMRT feladatban, kevésbé hatékonyan tudja kezelni a saját testével kapcsolatos információkat, sérültnek szorongónak tartja magát, míg az allocentrikus feladatban (TMRT) roszszul teljesítők nehezebben navigálnak a körülvevő térben, a disztális információk kezelése ineffektív, a közelítő-elkerülő viselkedés repertoár beszűkült.

Az említett egocentrikus és allocentrikus referenciákat a szorongó személyek rosszul használják. A figyelem fókuszának proximális és disztális referenciák közötti egyensúlyozásra lenne szükségük. Ezzel szemben - figyelmi funkcionális deficit kísérő jelenségeként - szélsőségesen, valamelyik referencia elkötelezett hívévé válnak, minek következtében a perceptuális mező beszűkül. Figyelmük nem oszcillál a disztális és proximális jelzések között, minek eredményeként tartós téri reprezentációs zavarok jönnek létre, melyek fenntartják, illetve tovább növelik a kognitív zavarok lehetőségét.

Záró megjegyzésünkben szeretnénk utalni arra, hogy a téri tájékozódás zavara eltérő módon jelenik meg különböző szorongásos állapotokban (LEVINSON, 1986). Az eltérés oka a téri reprezentáció torzulásában, a referenciakeretek működtetésében van. E reprezentáció módosítása a hatékony kognitív terápiás vezetés fontos részét képezheti.

\section{IRODALOM}

Andersen, R. A. (1988) The Neurobiological Basis of Spatial Cognition: Role of the Parietal Lobe, In Stile-Davis, J., Kritchevsky, M., Bellugi, U. (eds) Spatial Cognition: Brain Bases and Development, Academic Press, New York, 57-81.

Andersen, R. A., Snyder, L. H., Bradley, D. C., Xing, J. (1997) Multimodal representation of space in the posterior parietal cortex and its use in planning movements. Annual Review of Neurosciences, 20, 303-330.

AnnetT, M. (1970) A classification of hand preference by association analysis. Brithis Journal of Psychology, 61, 303-321.

ARRINDELL, W. (1993) The fear of fear concept: Evidence in favour of multi-dimensionality. Behavior Research and Therapy, 31, No. 5, 507-518. 
Beck, A. T., Emery, G., Greenberg, R. (1985) Anxiety Disoroders and Phobias. Basic Books, Inc., New York

Bonda, E., Petrides, M., Frey, S., Evans, A. (1995) Neuronal correlates of mental transformation of the body-in-space. Proc. Natl. Acad.Sci, USA. 92, 11180-11184.

Breitling, D., Guenther, W., Rondot, P. (1986) Motor responses by Brain Electrical Activity Mapping. Behavioural Neuroscience, 100, 1, 104-116.

Casey, M. B., Colon, D., Goris, Y. (1992) Family handendness as a predictor of mental rotation ability among minority girls in a math-science training program. Brain and Cognition, 18, 88-96.

Chapman, L. J., Chapman, J. P. (1987) The measurement of handendness. Brain and Cognition, 6, 175-183.

Charlot, V., Tzourio, N., Zilbovicius, M., Mazoyer, M., Denis, M. (1992) Different mental imagery abilities result in different regional cerebral blood flow activation patters during cognitive task. Neuropsychologia, 30, 6, 565-680.

Cohen, M. S., Kosslyn, S. M., Breiter, H. H., Di Girolamo, G. J., Thompson, W. L., Anderson, A. K., Bookheimer, S. Y., Rosen, B. R., Belliveau, J. W. (1996) Changes in cortical activity during mental rotation: A mapping study using functional MRI. Brain, 119, 89-100.

Corballis, M. C., Macadie, I., Beale, I. L. (1985) Mental rotation and visual laterality in normal and rigid disabled children. Cortex, 21, 2, 225-236.

Deutsch, G., Bourbon, W. T., Papanicolaou, A. C., Eisenberg, H. M. (1988) Visuospatial tasks compared via activation of regional cerebreal flow. Neuropsychologia, 26, 3, $445-452$.

Finke, R. A. (1980) Levels of equivalence of mental images and perception. Psychological Review, 87, 113-132.

Fischer, S. C., Pellegrino, J. W. (1988) Hemispheric differences for components of mental rotation. Brain and Cognition, 7, 1-15.

Gorman, J. M., Leibowitz, M. R., Fyer, A. J., Stein, J. (1989) A neuroanatomical hypothesis for panic disorder. The American Journal of Psychiatry, 146, 2, 1, 51-61.

IsAaC, A., Marks, D., Russel, D. (1986) An instrument for accessing imagery of movement: The Vividness of Movement Imagery Questionnaire (VMIQ) Journal of Mental Imagery, $10,23-30$

Jacobs, W. J., NADEL, L. (1985) Stress-induced recovery of fears and phobias. Psychological Review, Vol, 92, No. 4, 512-531.

Kállai, J., Kóczán, Gy., Szabó, I., Molnár, P., Varga, J. (1995) An experimental study to operationally define and measure spatial orientation in panic agoraphobic subjects, generalized anxiety and healthy control groups. Behaviour and Cognitive Psychoterapy, 23, $145-152$.

Kállai, J., Szabados, Zs., Varga, J., Ozsváth, K., Molnár, P., Kóczán, Gy. (1996) Opposite asymmetries in blind locomotor orientation of patients with panic agoraphobia compared to those with generalized anxiety. International Journal of Psychophysiology, 23, $155-161$.

Levinson, H. N. (1986) Phobia Free. M. Evans, New York

Linn, M. C., Petersen, A. C. (1985) Emergence and characterization of gender differences in spatial ability: Meta-analysis. Child Development, 56, 1479-1498. 
Margraf, J., Ehlers, A. (1989) Ethiological models of panic - Psychophysiological and Cognitive Aspects. In Baker, R. (ed.) Panic Disorder: Theory Research and Therapy. John Wiley and Sons, Chichester, 205-235.

Marks, I. M. (1987) Fears, Phobias and Rituals. Oxford University Press, New York

MORris, R. G. M. (1981) Spatial localization does not require the presence of locale cues. Learning and Motivation, 12, 239-260.

NAdEL, L., JACOBS, W. J. (1996) The role of the Hippocampus in PTSD, panic, and phobia. In Kato, N. (ed.) Hippocampus: Functions and Clinical Relevance. Elsevier Science B. V., Amsterdam, 455-463.

O' KeEfe, J., NADEL, L. (1978) The hippocampus as a cognitive map. Clarendon Press, Oxford

OLÁH A. (1987) STPI Szorongás, Düh, Kíváncsiság skáláinak tesztkönyve. MLKT. Módszertani Sorozat, 13. Budapest

Paillard, J. (1991) Motor and representational framing of space. In Paillard, J. (ed.) Brain and Space. Oxford University Press, New York

PERONnET, F., FARAh, M. J. (1989) Mental rotation: An event related potential study with a validated mental rotation task. Brain and Cognition, 9, 279-288.

Roland, P. E., Lassen, N. A., Larsen, B., Skinhoj, E. (1980) Supplementary motor area and other cortical areas in organisation of voluntary movements in man. Journal of Neurophysiology, 43, 1, 118-136.

Sandstrom, N. J., Kaufman, J., Huetel, A. A. (1998) Males and females use different distal cues in a virtual navigation task. Cognitive Brain Research, 6, 351-360.

SHEPARD, R. N. (1988) The role of transformations in spatial cognition. In Stiles-Davis, J., Kritchevsky, M., Bellugi, A. (eds) Spatial Cognition, Brain Bases and Development. Erlbaum, Hillsdale, 81-110.

Shepard, R. N., Metzler, J. (1971) Mental rotation of three-dimensional objects. Science, 171, 701-703.

Spieleberger, C. D., Jacobs, G., Crane, R., Russel, S., Westberry, L., Barker, L., Johson, E., Knight, J., Marks, E. (1980) Preliminary Manual for the State-Trait Personalitry Inventori (STPI), University of South Florida, Tampa

Stein, J. F. (1992) The representation of egocentric space in the posterior parietal cortex. Behavior and Brain Science, 15, 691-700.

Tagaris, G. A., Kin, S.-G., Strupp, J. P., Andersen, P., Ugurbil, K., Georgopoulos, A. P. (1996) Quantitative relations between parietal activation and performance in mental rotation. NeuroReport, 7, 773-776.

Uecker, A., Obruzut, J. (1993) Hemisphere and gender differences in mental rotation. Brain and Cognition, 22, 42-50.

VandenberG, S. G., Kuse, A. R. (1978) Mental rotation: A group test of three-dimensional spatial visualization. Perceptual and Motor Skills, 47, 599-604.

Williams, J. D., Rippon, G., Stone, B. M., Annett, J. (1995) Psychophysiological correlates of dinamic imaregy. British Journal of Psychology, 86, 283-300.

Wolpe, J., Lang, P. J. (1977) Manual for the Fear Survey Schedule. Educational and Industrial Testing Service, San Diego 


\title{
RELATION OF ALLOCENTRIC AND EGOCENTRIC SPATIAL REFERENCES TO SPATIAL SENSATIONS AND SELF-REPORTED ANXIETY
}

\author{
KÁLLAI, JÁNOS-KARÁDI, KÁZMÉR-KÓCZÁN, GYÖRGY-
} -RÉVÉSZ, GYÖRGY-HARTMAN, MÓNIKA

\begin{abstract}
Several symptoms encountered in psychological practice, such as anxiety, phobias, depression; they appear to involve abnormalities of the brain's representation of the outside world. These phenomena undoubtedly include some underlying disturbances of the basic machinery of spatial perception, cognition, and knowledge representation. The aim of the research reported in this paper is to seek anxiety components which may play a role in spatial cognitive functions under different types of dynamic imagery task. The object mental rotation test (MRT) and the hand mental rotation test (HMRT) is frequently used to test the dynamic spatial imagery. The completion of the MRT supported by dominantly allocentric reference frame in contrast the HMRT supported by egocentric references. Studying of anxiety components of allocentric MRT and egocentric HMRT together, the analysis of the items of the anxiety and fear questionnaires show that MRT is connected with those items that give answer to "What does the person do?" question in an allocentric social surrounding. In contrast, at HMRT there are dominantly egocentric questions that show connections with the "What I am like?" type question. Our results demonstrate that different forms of anxiety are connected with preferency of special spatial representation type. We can say, there are a biological based allocentric and egocentric spatial reference balances, which determine the symptoms and cognitive contents of the different kinds of anxiety.
\end{abstract}

Key words: allocentric, egocentric, spatial orientation, anxiety, mental rotation 